\title{
Permasalahan Anak Pendek (Stunting) dan Intervensi untuk Mencegah Terjadinya Stunting (Suatu Kajian Kepustakaan)
}

\section{Stunting Problems and Interventions to Prevent Stunting (A Literature Review)}

\section{Mitra}

\section{LPPM STIKes Hang Tuah Pekanbaru}

\begin{abstract}
Stunting is the nutritional problems in the world, especially occurred indeveloping and poor countries. Stuntingcan increase the risk of morbidity and mortality, and suboptimal brain development so that delayed motor development and mental retardation. Stuntingis a form ofgrowth failuredue tothe accumulation of nutrientin sufficiency from the beginning of pregnancy until 24 months old. This situation is exacerbated by inadequate catchup growth. In Indonesia, based of Basic Health Research, there was an increase of $36.8 \%$ stunted children in 2010 to37.2\% in 2013. Over the past 20 years, handling the problem of stunting is very slow. Globally, the percentage of children who were stunteddec lined by only 0.6 percent per year since 1990. WHO proposed a global target reduction in the incidence of stunting in children under five years old by 40\% in 2025, but it was predictedonly1536 countries that meetthose targets. The purpose of this article was examined the incidence of stunting reduction and interventions of the policy. Focus on movement to improve nutrition to target the first 1,000 days of life, in the global order it was called Scaling Up Nutrition (SUN) and in Indonesia called the National Movement for Nutrition Improvementin 1000 First Day of Life. The intervention consisted of specific interventions (short-term) and sensitive intervention (long-term).
\end{abstract}

Key word: Stunting, Scaling Up Nutrition, Intervention

\begin{abstract}
ABSTRAK
Masalah anak pendek (stunting) merupakan salah satu permasalahan gizi yang dihadapi di dunia, khususnya di negara-negara miskin dan berkembang. Stunting menjadi permasalahan karena berhubungan dengan meningkatnya risiko terjadinya kesakitan dan kematian, perkembangan otak suboptimal sehingga perkembangan motorik terlambat dan terhambatnya pertumbuhan mental. Stunting merupakan bentuk kegagalan pertumbuhan (growth faltering) akibat akumulasi ketidakcukupan nutrisi yang berlangsung lama mulai dari kehamilan sampai usia 24 bulan. Keadaan ini diperparah dengan tidak terimbanginya kejar tumbuh (catch up growth) yang memadai. Di Indonesia, berdasarkan Riskesdas 2013 terjadi peningkatan anak stunting dari 36,8\% pada tahun 2010 menjadi $37,2 \%$ pada tahun 2013. Selama 20 tahun terakhir, penanganan masalah stunting sangat lambat. Secara global, persentase anak-anak yang terhambat pertumbuhannya menurun hanya 0,6 persen per tahun sejak tahun 1990 . WHO mengusulkan target global penurunan kejadian stunting pada anak dibawah usia lima tahun sebesar $40 \%$ pada tahun 2025, namun diprediksikan hanya 15-36 negara yang memenuhi target tersebut. Tujuan dari artikel ini adalah untuk mengkaji kebijakan penanggulangan kejadian stunting dan intervensi yang dilakukan dari kebijakan tersebut. Fokus Gerakan perbaikan gizi ditujukan kepada kelompok 1000 hari pertama kehidupan, pada tatanan global disebut Scaling Up Nutrition (SUN) dan di Indonesia disebut dengan Gerakan Nasional Sadar Gizi dalam Rangka Percepatan Perbaikan Gizi Pada 1000 Hari Pertama Kehidupan. Intervensi yang dilakukan terdiri dari intervensi spesifik (jangka pendek) dan intervensi sensitif (jangka panjang).
\end{abstract}

Kata Kunci : Stunting, Scaling Up Nutrition, Intervensi

\footnotetext{
${ }^{1}$ Alamat Korespodensi: Mitra, Program Studi Magister Ilmu Kesehatan Masyarakat STIKes Hang Tuah Pekanbaru, Jln. Mustafa Sari No 5 Tangerang Selatan Pekanbaru, Hp:08126731772, email : mitra_harau@yahoo.co.id
} 


\section{PENDAHULUAN}

Masalah anak pendek (stunting) merupakan salah satu permasalahan gizi yang dihadapi di dunia, khususnya di negara-negara miskin dan berkembang (Unicef, 2013). Stunting menjadi permasalahan karena berhubungan dengan meningkatnya risiko terjadinya kesakitan dan kematian, perkembangan otak suboptimal sehingga perkembangan motorik terlambat dan terhambatnya pertumbuhan mental (Lewit, 1997; Kusharisupeni, 2002; Unicef, 2013). Beberapa studi menunjukkan risiko yang diakibatkan stunting yaitu penurunan prestasi akademik (Picauly \& Toy, 2013), meningkatkan risiko obesitas (Hoffman et al, 2000; Timaeus, 2012) lebih rentan terhadap penyakit tidak menular (Unicef Indonesia, 2013) dan peningkatan risiko penyakit degeneratif (Picauly \& Toy, 2013, WHO, 2013, Crookston et al 2013). Penelitian kohort prospektif di Jamaika, dilakukan pada kelompok usia 9-24 bulan, diikuti perkembangan psikologisnya ketika berusia 17 tahun, diperoleh bahwa remaja yang terhambat pertumbuhannya lebih tinggi tingkat kecemasan, gejala depresi, dan memiliki harga diri (self esteem) yang rendah dibandingkan dibandingkan dengan remaja yang tidak terhambat pertumbuhannya. Anak-anak yang terhambat pertumbuhannya sebelum berusia 2 tahun memiliki hasil yang lebih buruk dalam emosi dan perilakunya pada masa remaja akhir (Walker et al 2007). Oleh karena itu stunting merupakan prediktor buruknya kualitas sumber daya manusia yang selanjutnya akan berpengaruh pada pengembangan potensi bangsa (Unicef, 2013; Unicef Indonesia, 2013).

Stunting merupakan bentuk kegagalan pertumbuhan (growth faltering) akibat akumulasi ketidakcukupan nutrisi yang berlangsung lama mulai dari kehamilan sampai usia 24 bulan (Hoffman et al, 2000; Bloem et al, 2013). Keadaan ini diperparah dengan tidak terimbanginya kejar tumbuh (catch up growth) yang memadai (Kusharisupeni, 2002; Hoffman et al, 2000). Indikator yang digunakan untuk mengidentifikasi balita stunting adalah berdasarkan indeks Tinggi badan menurut umur $(\mathrm{TB} / \mathrm{U})$ menurut standar WHO child growth standart dengan kriteria stunting jika nilai $\mathrm{z}$ score $\mathrm{TB} / \mathrm{U}<-2$ Standard Deviasi (SD) (Picauly \& Toy, 2013; Mucha, 2013).Periode 024 bulan merupakan periode yang menentukan kualitas kehidupan sehingga disebut dengan periode emas. Periode ini merupakan periode yang sensitif karena akibat yang ditimbulkan terhadap bayi pada masa ini akan bersifat permanen dan tidak dapat dikoreksi. Untuk itu diperlukan pemenuhan gizi yang adekuat pada usia ini (Mucha, 2013).

Banyak faktor yang menyebabkan tingginya kejadian stunting pada balita. Penyebab langsung adalah kurangnya asupan makanan dan adanya penyakit infeksi (Unicef, 1990; Hoffman, 2000; Umeta, 2003). Faktor lainnya adalah pengetahuan ibu yang kurang, pola asuh yang salah, sanitasi dan hygiene yang buruk dan rendahnya pelayanan kesehatan (Unicef, 1990). Selain itu masyarakat belum menyadari anak pendek merupakan suatu masalah, karena anak pendek di masyarakat terlihat sebagai anak-anak dengan aktivitas yang normal, tidak seperti anak kurus yang harus segera ditanggulangi. Demikian pula halnya gizi ibu waktu hamil, masyarakat belum menyadari pentingnya gizi selama kehamilan berkontribusi terhadap keadaan gizi bayi yang akan dilahirkannya kelak (Unicef Indonesia, 2013).

Millenium Development Goals (MDGs) merupakan suatu deklarasi pembangunan millennium yang berpihak kepada pemenuhan hak-hak dasar manusia yang mengarah pada peningkatan kualitas hidup. MDGs menetapkan 8 tujuan pembangunan yang diuraikan menjadi 18 target dan 48 indikator. Tujuan 1 dan 4 difokuskan pada penurunan kelaparan dan kematian balita, tetapi tidak ada indikator khusus untuk stunting dalam tujuan tersebut (Unicef, 2013; Cobham et al, 2013). Selama 20 tahun terakhir, penanganan masalah stunting sangat lambat. Secara global, persentase anak-anak yang terhambat pertumbuhannya menurun hanya 0,6 persen per tahun sejak tahun 1990. Diprediksi, jika hal tersebut berlangsung terus, maka 15 tahun kemudian, diperkirakan 450 juta anak-anak mengalami keterlambatan pertumbuhan (stunting) (Cobham et al, 2013). Dalam menyingkapi tingginya prevalensi stunting ini, yang terkonsentrasi di beberapa dunia negara-negara termiskin, Organisasi Kesehatan Dunia (WHO) telah mengusulkan target global penurunan kejadian stunting pada anak dibawah usia lima tahun sebesar $40 \%$ pada tahun 2025. Tiga negara dari Afrika yaitu Malawi, Niger dan Zambia diproyeksikan penurunannya hanya sebesar $0-2 \%$, sementara dilebih lima negara Afghanistan, Burkina Faso, Madagaskar, Tanzania dan Yaman pengurangan diproyeksikan kurang dari $20 \%$ atau setengah diusulkan sasaran(Unicef, 2013; Cobham et al, 2013). Untuk itu diperlukan strategi dan respon yang tepat dalam mengatasi dan menurunkan prevalensi kejadian stunting. Tujuan dari artikel ini adalah untuk mengkaji kebijakan penanggulangan kejadian stunting dan intervensi yang dilakukan dari kebijakan tersebut.

\section{Faktor determinan dan dampak stunting}

Permasalah gizi adalah permasalahan dalam siklus kehidupan, mulai dari kehamilan, bayi, balita, remaja, sampai dengan lansia. Masalah gizi dapat terjadi pada seluruh kelompok umur, bahkan masalah gizi pada suatu kelompok umur tertentu akan mempengaruhi pada status gizi pada periode siklus kehidupan berikutnya (intergenerational impact) (Republik Indonesia, 2012).

Masalah kekurangan gizi diawali dengan perlambatan atau retardasi pertumbuhan janin yang dikenal sebagai IUGR (Intra Uterine Growth 
Retardation). Di negara berkembang,kurang gizi pada pra-hamil dan ibu hamil berdampak pada lahirnya anak yang IUGR dan Berat Badan Lahir Rendah (BBLR). Kondisi IUGR hampir separuhnya terkait dengan status gizi ibu, yaitu berat badan (BB) ibu pra-hamil yang tidak sesuai dengan tinggi badan ibu atau bertubuh pendek, dan pertambahan berat badan selama kehamilannya (PBBH) kurang dari seharusnya. Ibu yang pendek waktu usia 2 tahun cenderung bertubuh pendek pada saat meninjak dewasa. Apabila hamil ibu pendek akan cenderung melahirkan bayi yang BBLR. Ibu hamil yang pendek membatasi aliran darah rahim dan pertumbuhan uterus, plasenta dan janin sehingga akan lahir dengan berat badan rendah (Kramer, 1987). Apabila tidak ada perbaikan, terjadinya IUGR dan BBLR akan terus berlangsung di generasi selanjutnya sehingga terjadi masalah anak pendek intergenerasi (Unicef, 2013; Republik Indonesia, 2012; Sari et al, 2010). Gizi ibu dan status kesehatan sangat penting sebagai penentu stunting. Seorang ibu yang kurang gizi lebih mungkin untuk melahirkan anak terhambat, mengabadikan lingkaran setan gizi dan kemiskinan (Unicef, 2013).

Pemenuhan zat gizi yang adekuat, baik gizi makro maupun gizi mikro sangat dibutuhkan untuk menghindari atau memperkecil risiko stunting. Kualitas dan kuantitas MP-ASI yang baik merupakan komponen penting dalam makanan karena mengandung sumber gizi makro dan mikro yang berperan dalam pertumbuhan linear (Taufiqurrahman et al, 2009). Pemberian makanan yang tinggi protein, calsium, vitamin A, dan zinc dapat memacu tinggi badan anak (Koesharisupeni, 2002). Pemberian asupan gizi yang adekuat berpengaruh pada pola pertumbuhan normal sehingga dapat terkejar (catch up) (Rahayu, 2011).

Frekuensi pemberian MP-ASI yang kurang dan pemberian MP-ASI/susu formula terlalu dini dapat meningkatkan risiko stunting (Padmadas et al, 2002; Hariyadi \& Ekayanti, 2011). Pengaturan dan kualitas makanan yang diberikan kepada bayi sangat tergantung kepada pendidikan dan pengetahuan ibu dan ketersediaan bahan makanan di tingkat rumah tangga. Kesadaran ibu terhadap gizi yang baik diberikan kepada anak memegang peranan yang penting dalam menjaga kualitas makanan yang diberikan. Penelitian menunjukkan bahwa rumah tangga dengan perilaku sadar gizi yang kurang baik berpeluang meningkatkan risiko kejadian stunting pada anak balita 1,22 kali dibandingkan dengan rumah tangga dengan perilaku kesadaran gizi baik (Riyadi et al, 2011). Penelitian di Nusa Tenggara Timur menunjukkan bahwa peran ibu sebagai "gate keeper" dalam menjaga konsumsi dan status gizi rumah tangga terlihat sangat menonjol. Peran itu terlihat dari pengaruh pengetahuan gizi ibu, akses informasi gizi dan kesehatan, praktek gizi dan kesehatan ibu dan alokasi pengeluaran pangan dan non pangan (pendapatan) (Picauly \& Magdalena, 2013). Penelitian lain yang dilakukan di Kenya menunjukkan bahwa peningkatan risiko stunting signifikan pada anak-anak yang diadopsi (Bloss, 2004). Penelitian di Ethiopia mengidentifikasi factor yang terkait dengan tingginya stunting pada bayi yang diberi ASI. Hasilnya menunjukkan bahwa bayi dari ibu yang mempunyai konsentrasi seng yang rendah dalam ASI lebih banyak yang stunting (Assefa et al, 2013). Untuk itu perlu meningkatkan pasokan nutrisi dengan memberikan tambahan makanan lainnya/suplemen dan tetap memberikan ASI kepada bayi. Balita yang tidak lagi menyusui mempunyai risiko 2 kali lebih besar mengalami stunting dibandingkan dengan balita yang masih menyusui (Taufiqurrahman et al, 2009).

Faktor determinan lainnya yang berhubungan dengan kejadian stunting adalah faktor sosial ekonomi. Status'sosial ekonomi, usia, jenis kelamin dan pendidikan ibu merupakan faktor penting dari status gizi remaja (underweight dan stunting) (Assefa, 2013). Penelitian yang dilakukan di negara yang berpendapatan menengah dan rendah menunjukkan bahwa anak-anak yang tinggal di daerah kumuh, semakin bertambahnya usia anak memperburuk risiko untuk stunting (Kyu \& Shannon, 2013). Kesehatan anak juga menjadi faktor penentu kejadian stunting. Berulang atau berkepanjangan episode diare selama masa kanak-kanak meningkatkan risiko stunting (Ricci et al, 2013).

\section{Prevalensi Stunting di Indonesia}

Riset Kesehatan dasar (Riskesdas) menunjukan bahwa terjadi peningkatan prevalensi stunting di Indonesia dari 36,8 \% pada tahun 2007 menjadi $37,2 \%$ pada tahun 2013 , artinya 1 dari 3 anak Indonesia tergolong pendek (Riskesdas, 2013).

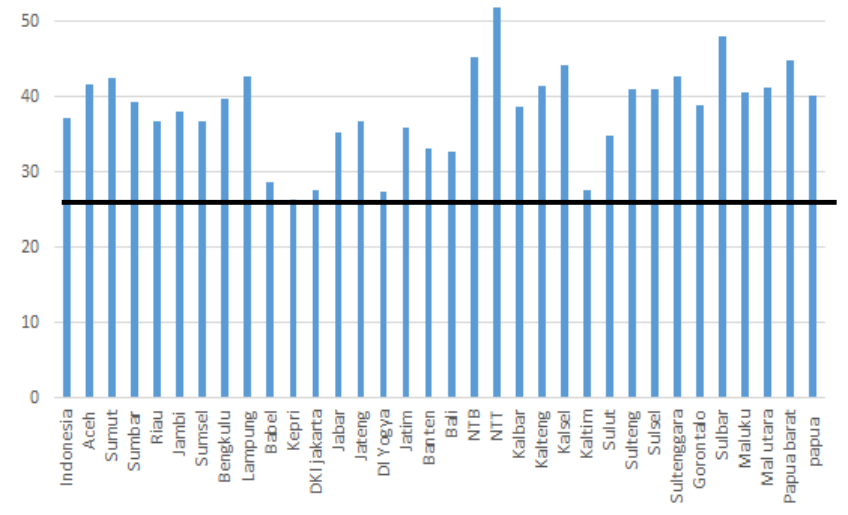

Gambar 1. Prevalensi stunting di Indonesia Sumber : Riskesdas, 2013

Prevalensi anak pendek di Indonesia bervariasi dari nrevalensi menenoah samnai sanoat tinooi 
Prevalensi tertinggi berada di Nusa Tenggara Timur (NTT) dan terendah di Kepulauan Riau. Hanya 5 provinsi yang mempunyai prevalensi kurang dari 30 persen yaitu Kepulauan Riau, Yogyakarta, DKI, Kalimantan Timur dan Bangka Belitung (Gambar 1).

Berdasarkan kelompok umur pada balita, semakin bertambah umur prevalensi stunting semakin meningkat. Prevalensi stunting paling tinggi pada usia 24-35 bulan yaitu sebesar $42,0 \%$ dan menurun pada usia 36-47 bulan (Gambar 2). Stunting lebih banyak terjadi pada anak laki-laki $(38,1 \%)$ dibandingkan dengan anak perempuan $(36,2 \%)$. Daerah perdesaan $(42,1 \%)$ mempunyai prevalensi stunting yang lebih tinggi dibandingkan daerah perkotaan (32,5\%). Menurut tingkat kepemilikan atau ekonomi penduduk, stunting lebih banyak terjadi pada mereka yang berada pada kuintil terbawah (Gambar 3) (Riskesdas, 2013).

Prevalensi kejadian stunting lebih tinggi dibandingkan dengan permasalahan gizi lainnya seperti gizi kurang $(19,6 \%)$, kurus $(6,8 \%)$ dan kegemukan $(11,9 \%)$ (Riskesdas, 2013). Dibandingkan dengan negara ASEAN, prevalensi stunting di Indonesia berada pada kelompok high prevalence, sama halnya dengan negara Kamboja dan Myanmar (Bloem et al, 2013). Dari 556 juta balita di negara berkembang 178 juta anak (32\%) bertubuh pendek dan 19 juta anak sangat kurus $(<-3 \mathrm{SD})$ dan 3.5 juta anak meninggal setiap tahun (Black et al, 2008; Cobham, 2013).

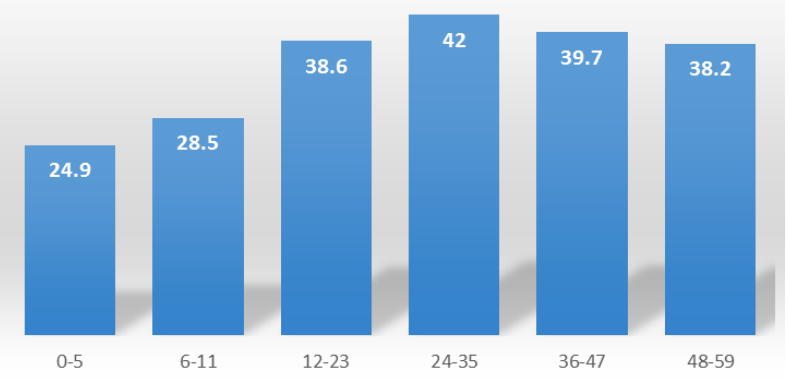

Gambar 2. Prevalensi stunting menurut kelompok umur di Indonesia Sumber : Risdesdas, 2013

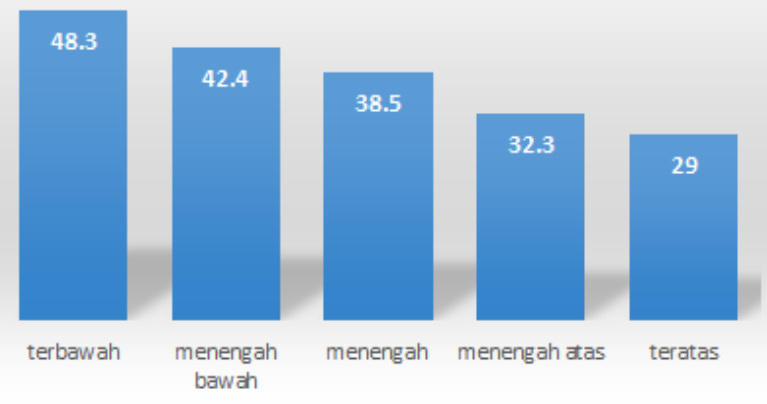

Gambar 3. Prevalensi stunting menurut tingkat ekonomi di Indonesia

Sumber : Risdesdas, 2013

\section{Prevalensi Stunting di dunia}

Secara global, pada tahun 2010 prevalensi anak pendek sebesar 171 juta anak-anak di mana 167 juta kejadian terjadi di negara berkembang. Prevalensi stunting pada anak menurun dari 39,7 ( $95 \%$ CI: 38,1$41,4) \%$ pada tahun 1990 menjadi 26,7 (95\% CI; 24, 8 $-28,7) \%$ pada tahun 2010 . Tren ini diperkirakan akan mencapai $21,8(95 \%$ CI: $19,8-23,8) \%$ atau 142 juta pada tahun 2020 (Onis et al, 2011).

Prevalensi stunting di Afrika mengalami stagnasi sejak tahun 1990 sekitar 40\%, sementara di Asia menunjukkan penurunan dramatis dari $49 \%$ pada tahun 1990 menjadi 28\% pada tahun 2010 (Onis et al, 2011). Penerapan Manajemen Terpadu Balita Sakit di Bangladesh dapat menurunkan prevalensi stunting pada anak-anak yang berusia $24-59$ bulan dari $63,1 \%$ menjadi 50,4 \% (yaitu pengurangan absolut $13 \%$ atau pengurangan relatif rata-rata $4,5 \%$ per tahun (Unicef, 2013). Pengurangan stunting juga telah didokumentasikan di beberapa negara di Amerika Selatan. Prevalensi stunting di Brazil menurun dari 37 $\%$ pada tahun 1974-1975 menjadi $7 \%$ pada tahun 2006-2007, dengan kata lain adanya pengurangan relatif rata-rata $5,2 \%$ per tahun selama 32 tahun (Unicef, 2013). Di Meksiko prevalensi stunting menurun dari $27 \%$ pada tahun 1988 menjadi $16 \%$ pada tahun 2006 (pengurangan absolut $11 \%$ atau relatif rata-rata pengurangan $2,9 \%$ per tahun). Studi observasional di sembilan negara Sub Sahara Afrika pada anak-anak pada anak-anak yang berusia dibawah dua tahun menunjukkan bahwa prevalensi stunting turun $43 \%$ dalam tiga tahun pelaksanaan program Scaling Up Nutrition (SUN) (Unicef, 2013).

\section{Kebijakan Penanggulangan Stunting}

Landasan kebijakan program pangan dan gizi dalam jangka panjang dirumuskan dalam Undang-Undang No.17 tahun 2007 tentang Rencana Pembangunan Jangka Panjang Nasional (RPJPN) tahun 2005-2025. Pendekatan multi sektor dalam pembangunan pangan dan gizi meliputi produksi, pengolahan, distribusi, hingga konsumsi pangan, dengan kandungan gizi yang cukup, seimbang, serta terjamin keamanannya. Pembangunan jangka panjang dijalankan secara bertahap dalam kurun waktu lima tahunan, dirumuskan dalam dokumen Rencana Pembangunan Jangka Menengah Nasional (RPJMN) yang ditetapkan dalam Peraturan Presiden. Dalam RPJMN tahap ke-2 periode tahun 2010-2014, terdapat dua indikator outcome yang berkaitan dengan gizi yaitu prevalensi kekurangan gizi (gizi kurang dan gizi buruk) sebesar $<15$ persen dan prevalensi stunting (pendek) sebesar 32 persen pada akhir 2014. Sasaran program gizi lebih difokuskan terhadap ibu hamil sampai anak usia 2 tahun (Republik Indonesia, 2012).

Fokus Gerakan perbaikan gizi adalah kepada kelompok 1000 hari pertama kehidupan, pada tataran 
global disebut dengan Scaling Up Nutrition (SUN) dan di Indonesia disebut dengan Gerakan Nasional Sadar Gizi dalam Rangka Percepatan Perbaikan Gizi Pada 1000 Hari Pertama Kehidupan (Gerakan 1000 Hari Pertama Kehidupan dan disingkat Gerakan 1000 HPK). SUN movement merupakan upaya global dari berbagai negara dalam rangka memperkuat komitmen dan rencana aksi percepatan perbaikan gizi, khususnya penanganan gizi sejak 1.000 hari dari masa kehamilan hingga anak usia 2 tahun. Gerakan ini merupakan respon negara-negara di dunia terhadap kondisi status gizi di sebagian besar negara berkembang dan akibat kemajuan yang tidak merata dalam mencapai Tujuan Pembangunan Milenium/MDGs (Goal 1) (Republik Indonesia, 2012).

Gerakan SUN merupakan upaya baru untuk menghilangkan kekurangan gizi dalam segala bentuknya. Prinsip gerakan ini adalah semua orang memiliki hak atas pangan dan gizi yang baik. Hal ini merupakan suatu yang unik karena melibatkan berbagai kelompok masyarakat yang berbeda-beda baik pemerintah, swasta, LSM, ilmuwan, masyarakat sipil, dan PBB secara bersama-sama melakukan tindakan kolektif untuk peningkatan gizi. Intervensi yang dilakukan pada SUN adalah intervensi spesifik dan intervensi sensitif (Scaling Up Nutrition, 2013).

Intervensi spesifik adalah tindakan atau kegiatan yang dalam perencanaannya ditujukan khusus untuk kelompok 1000 hari pertama kehidupan (HPK) dan bersifat jangka pendek. Kegiatan ini pada umumnya dilakukan pada sektor kesehatan, seperti imunisasi, PMT ibu hamil dan balita, monitoring pertumbuhan balita di Posyandu, suplemen tablet besi-folat ibu hamil, promosi ASI Eksklusif, MP-ASI, dan sebagainya. Sedangkan intervensi sensitif adalah berbagai kegiatan pembangunan di luar sektor kesehatan yang ditujukan pada masyarakat umum. Beberapa kegiatan tersebut adalah penyediaan air bersih, sarana sanitasi, berbagai penanggulangan kemiskinan, ketahanan pangan dan gizi, fortifikasi pangan, pendidikan dan KIE Gizi, pendidikan dan KIE Kesehatan, kesetaraan gender, dan lain-lain (Republik Indonesia, 2013).

Pada awal tahun 2013, terdapat 33 negara SUN bagi 59 juta anak stunting yang mewakili sekitar sepertiga dari semua anak stunting di dunia. Tingkat rata-rata pengurangan stunting per tahun di 33 negara tersebut adalah 1,8 \%. WHO merekomendasikan pengurangan stunting 3,9\% per tahun dalam rangka memenuhi target global pengurangan stunting pada tahun 2025 sebesar 40\% (Scaling Up Nutrition, 2013).

\section{Intervensi pada Penanggulangan Stunting}

Intervensi efektif dibutuhkan untuk mengurangi stunting, defisiensi mikronutrien, dan kematian anak . Jika diterapkan pada skala yang cukup maka akan mengurangi (semua kematian anak) sekitar seperempat dalam jangka pendek. Dari intervensi yang tersedia, konseling tentang pemberian ASI dan fortifikasi atau suplementasi vitamin A dan seng memiliki potensi terbesar untuk mengurangi beban morbiditas dan mortalitas anak. Peningkatan makanan pendamping ASI melalui strategi seperti penyuluhan tentang gizi dan konseling gizi, suplemen makanan di daerah rawan pangan secara substansial dapat mengurangi stunting dan beban terkait penyakit. Intervensi untuk gizi ibu (suplemen folat besi, beberapa mikronutrien, kalsium, dan energi dan protein yang seimbang) dapat mengurangi risiko berat badan lahir rendah sebesar 16\%. Direkomendasikan pemberian mikronutrien untuk anak-anak seperti suplementasi vitamin A (dalam periode neonatal dan akhir masa kanak-kanak), suplemen zinc, suplemen zat besi untuk anak-anak di daerah malaria tidak endemik, dan promosi garam beryodium. Untuk intervensi pengurangan stunting jangka panjang, harus dilengkapi dengan perbaikan dalam faktor-faktor penentu gizi, seperti kemiskinan, pendidikan yang rendah, beban penyakit, dan kurangnya pemberdayaan perempuan (Bhutta, 2008).

Intervensi penanggulangan stunting juga difokuskan pada masyarakat termiskin. Hal ini penting dilakukan untuk mencapai target yang diusulkan WHO. Perhatian khusus diberikan kepada 36 negara high burden (Cobham, 2013).Kebijakan gizi nasional dan organisasi internasional harus memastikan bahwa kesenjangan yang terjadi ditangani dengan mengutamakan gizi di daerah pedesaan dan kelompokkelompok termiskin dalam masyarakat. Kebijakan yang mendukung distribusi yang lebih adil dari pendapatan nasional, seperti kebijakan perlindungan sosial, memainkan peranan penting dalam meningkatkan gizi (Cobham, 2013). Intervensi lainnya dilakukan untuk penangulangan stunting ditekankan kepada pemberian imunisasi, peningkatan pemberian ASI eksklusif dan akses makanan yang kaya gizi di kalangan anak-anak yang diadopsi dan keluarga mereka melalui intervensi gizi berbasis masyarakat (Bloss, 2004).

Penelitian di sembilan negara Sub Sahara Afrika menunjukkan diperlukan intervensi multisektor dalam penanggulangan stunting. Strategi yang dilakukan adalah dengan menggabungkan gizi spesifik, pendekatan berbasis kesehatan dengan sistem intervensi berbasis mata pencaharian. Hasilnya menunjukkan dalam tiga tahun setelah dimulainya program ini pada tahun 2005-2006 perbaikan yang konsisten dalam ketahanan pangan rumah tangga dan keragaman diet (Remans, 2011).

Analisis terhadap pola pertumbuhan awal pada anak-anak dari 54 negara miskin di Afrika dan Asia Tenggara menunjukkan bahwa terjadinya peningkatan stunting selama 2 tahun pertama kehidupan dan tidak ada pemulihan sampai dengan usia 5 tahun. Temuan ini memusatkan perhatian pada periode 9-24 bulan 
sebagai "window of opportunity" untuk intervensi terhadap stunting. Dukungan politik yang cukup besar dibutuhkan untuk investasi pada 1000 hari pertama kehidupan. Data pertumbuhan longitudinal dari Gambia pedesaan menunjukkan bahwa substansial catch-up terjadi antara 24 bulan dan pertengahan masa kanak-kanak, serta antara pertengahan masa kanakkanak dan dewasa. Data ini menggambarkan bahwa fase pertumbuhan pubertas memungkinkan pemulihan tinggi badan sangat besar, terutama pada anak perempuan selama masa remaja. Berdasarkan temuan tersebut, intervensi stunting dilakukan pada setiap siklus kehidupan sehingga efek intergenerasi dapat dihindari (Remans, 2011).Para pembuat kebijakan dan perencana program harus mempertimbangkan dan melipatgandakan upaya untuk mencegah stunting danmeningkatkan pertumbuhan catch-up pada tahun pertama kehidupan dan juga pada fase purbertas untuk mengurangi dampak buruk yang diakibatkan oleh stunting.

Intervensi yang dilakulan dalam rangka mempercepat pengurangan stunting di Asia Tenggara adalah meningkatkan ketersediaan dan akses makanan bergizi dengan melakukan kolaborasi antara swasta dan sektor publik. Asosiasi Negara-negara Asia Tenggara ( ASEAN) dapat memainkan peran sebagai fasilitator. Sektor swasta dapat memproduksi dan memasarkan makanan bergizi, sedangkan sektor publik menetapkan standar, mempromosikan makanan sehat dan bergizi, dan menjamin akses makanan bergizi untuk daerah termiskin, misalnya melalui programprogram jaring pengaman sosial (Bloem, 2013).

Di Brasil pengurangan stunting telah dikaitkan untuk meningkatkan daya beli keluarga berpenghasilan rendah, meningkatkan tingkat pendidikan ibu, penyediaan air bersih dan sistem pembuangan, dan universalisasi virtual perawatan kesehatan dasar, termasuk perawatan prenatal. DiAfrika, dilakukan program perbaikan ketahanan pangan rumah tangga, keragaman diet dan peningkatan intervensi cakupan perawatan anak dan penyakit (Unicef, 2013).

\section{KESIMPULAN}

Masalah stunting merupakan permasalahan gizi yang dihadapi dunia khususnya negara-negara miskin dan berkembang. Stunting merupakan kegagalan pertumbuhan akibat akumulasi ketidakcukupan nutrisi yang berlangsung lama mulai dari kehamilan sampai dengan usia 24 bulan. Banyak faktor yang menyebabkan tingginya kejadian stunting pada balita. Masyarakat belum menyadari stunting sebagai suatu masalah dibandingkan dengan permasalahan kurang gizi lainnya. Secara global kebijakan yang dilakukan untuk penurunan kejadian stunting difokuskan pada kelompok 1000 hari pertama atau yang disebut dengan Scaling Up Nutrition. WHO merekomendasikan penurunan stunting sebesar 3,9\% pertahun dalam rangka memenuhi target $40 \%$ penurunan stunting pada tahun 2025. Intervensi dilakukan pada sepanjang siklus kehidupan baik di sektor kesehatan maupun non kesehatan yang melibatkan berbagai lapisan masyarakat seperti pemerintah, swasta, masyarakat sipil, PBB melalui tindakan kolektif untuk peningkatan perbaikan gizi, baik jangka pendek (intervensi spesifik) maupun jangka panjang (sensitif).

\section{DAFTAR PUSTAKA}

Assefa H, Belachew T, Negash L, 2013.Socioeconomic Factors Associated with Underweight and Stunting among Adolescents of Jimma Zone, South West Ethiopia: A Cross-Sectional Study. Hindawi Publishing Corporation ISRN Public Health Volume Article ID 238546, 7 pages http://dx.doi.org/10.1155/2013/238546

Bhutta ZA, Ahmed T, Black RE, Cousens S, Dewey K, Giugliani E, Haider BA, Kirkwood B, Morris SS, Sachdev HPS, Shekar M, 2008. What works? Interventions for maternal and child undernutrition and survival. Journal Lancet, January 17, 2008 DOI:10.1016/S0140-6736(07)61693-6 www.thelancet.com

Black RE, Allen LH, Bhutta ZA, 2008 Maternal and Child Undernutrition Study Group. Maternal and child undernutrition: global and regional exposures and health consequences. Lancet Journal 2008. published online Jan 17. DOI: 10.1016/S01406736(07)61690-0.

Bloem MW, Pee SD, Hop LT, Khan NC, Laillou A, Minarto, Pfanner RM, Soekarjo D, Soekirman, Solon JA, Theary C, Wasantwisut E, 2013.Key strategies to further reduce stunting in Southeast Asia: Lessons from the ASEAN countries workshop. Food and Nutrition Bulletin: 34:2

Bloss E, Wainaina F, Bailey RC, 2004. Prevalence and Predictors of Underweight, Stunting, and Wasting among Children Aged 5 and Under in Western Kenya. Journal of Tropical Pediatrics, 50:5

Cobham A, Garde M, Crosby L, 2013.Global Stunting Reduction Target: Focus On The Poorest Or Leave Millions Behind, Akses www.savethechildren.org.ukTanggal 26 Desember 2013. 
Crookston B, Penny M, Alder SC, Dickerson T, Merrill RM, Stanford J , Porucznik CA, Dearden KA, 2010.Children Who Recover from Early Stunting and Children Who Are Not Stunted Demonstrate Similar Levels of Cognition. American Society for Nutrition. 2010; doi:10.3945/ jn.109.118927.

Hariyadi D, Ekayanti I, 2011.Analisis pengaruh perilaku keluarga sadar gizi terhadap stunting di Propinsi Kalimantan Barat, Teknologi dan Kejuruan, 34 :1,:71-80

Hoffman DJ, Sawaya AL, Verreschi I, Tucker KL, Roberts SB, 2000. Why are nutritionally stunted children at increased risk of obesity? Studies of metabolic rate and fat oxidation in shantytown children from São Paulo, Brazil. Am J Clin Nutrition 72:702-7

Intje Picaly, Sari, 2013. Analisis Determinan dan Pengaruh Stunting terhadap Prestasi Belajar. Journal Gizi dan Pangan : 8 (1)

Kramer MS, 1987. Determinans of low birth weight : methodological assessment and metaanalysis. Bulletin World Health Organization, 65 (5) : 663-737

Kusharisupeni, 2002. Peran status kelahiran terhadap stunting pada bayi : sebuah studi prospektif, Jurnal Kedokteran Trisakti, 2002,23: 73-80

Kusharisupeni, 2002.Growth Faltering pada Bayi di Kabupaten Indramayu Jawa Barat. Makara Kesehatan, 2002, 6:1-5

Kyu HH, Shannon HS, Georgiades K, Boyle MH, 2013.Association of Urban Slum Residency with Infant Mortality and Child Stunting in Low and Middle Income Countries. Hindawi Publishing Corporation BioMed Research International Volume, Article ID 604974, 12 pages http://dx.doi.org/10.1155/2013/604974

Lewit EM, Kerrebrock N. 1997Population-Based Growth Stunting, The Future Of Children Children And Poverty 7:2

MuchaN, 2012.Implementing Nutrition-Sensitive Development: Reaching Consensus.briefing paper,Akses:www.bread.org/institute/papers/n utrition-sensitive-interventions.pdf tanggal 26 Desember 2013

Onis M, Monika B, Borghi E, 2011.Prevalence and trends of stunting among pre-school children,1990-2020, Public Health Nutrition: page 1-7 doi:10.1017/S1368980011001315.

Padmadas SS, Hutter I, Willekens F, 2002.Weaning Initiation patterns and subsequents linear growth progression among children aged 24 years in India. International Journal of Epidemiology, 31:855-63

Picauly I, Magdalena S, 2013.Analisis determinan dan pengaruh stunting terhadap prestasi belajar anak sekolah di Kupang dan Sumba Timur, NTT. Jurnal Gizi dan Pangan,8(1): $55-62$

Prentice AM, Ward KA, Goldberg GR, Jarjou LM, Moore SE, Fulford AJ, Prentice A, 2013.Critical windows for nutritional interventions against stunting, Am J Clin Nutr. 97:911-8

Rahayu LS, 2011.Associated of Health of Parents with changes of Stunting from 6-12 months to 3-4 years (Tesis): Yogyakarta, Universitas Gajah Mada.

Remans R, Pronyk PM, Fanzo JC, Chen JH, Palm CA, Nemser B, Muniz M,Radunsky A, Abay AH, Coulibaly M, Homiah JM, Wagah M, An X,Mwaura C, Quintana E, Somers MA, Sanchez PA, Sachs SE, McArthur JW, Sachs JD, 2011.Multisector intervention to accelerate reductions in child stunting: anobservational study from 9 sub-Saharan African countries. American Society for Nutrition doi: 10.3945/ajcn.111.020099.

Republik Indonesia, 2012. Kerangka Kebijakan Gerakan Sadar Gizi dalam rangka Seribu Hari Kehidupan (1000 HPK) versi 5 September 2012. Diakses dari http://www. kgm.bappenas.go.id tanggal 16 Desember 2013.

Ricci KA, Girosi F, Tarr PI, LimYW, Mason C, Miller M, Hughes J, Seidlein L, Agosti JM, Guerrant RL, 2013.Reducing stunting among children: the potential contribution of diagnostics. Nature Publishing Group p:29-38 diakses:http://www.nature.com/diagnosticstan ggal 27 Desember 2013

Riskesdas, 2013. Penyajian Pokok-pokok Hasil Riset Kesehatan Dasar 2013. Badan Penelitian dan Pengembangan Kesehatan, Kementerian Kesehatan RI. Akses www.litbang.depkes.go.id tanggal 10 Desember 2013.

Riyadi H, Martianto D, Hastuti D, Damayanthi E, Murtilaksono K, 2011.Faktor-Faktor Yang Mempengaruhi Status Gizi Anak Balita Di Kabupaten Timor Tengah Utara, Provinsi Nusa Tenggara Timur. Jurnal Gizi dan Pangan, 6(1): 66-73. 
Sari M, Dee Sd, Bloem MW, Sun K, Thorm L, Moench Pfanner R, 2010. Higher household expenditure on animal source and nograim foods lowers the risk of stunting among children 0-59 months old in Indonesia. Implications of rising food prices. The Journal of Nutrition, 140:196-200

Scaling Up Nutrition, 2013. Country Progress In scaling up nutrition. Januari 2013 Akses scalingupnutrition.org/resources tanggal 26 Desember 2013

Taufiqurrahman, Hadi H, Julia M, Herman S, 2009.Defisiensi Vitamin A Dan Zinc Sebagai Faktor Risiko Terjadinya Stunting Pada Balita Di Nusa Tenggara Barat, Media Penelitian dan Pengembangan Kesehatan. 29 :

2

Timæus, IM, 2012. Stunting and obesity in childhood: are assessment using longitudinal data from South Africa, International Journal of Epidemiology;1-9 doi:10.1093/ije/dys026.

Umeta M, West CE, Verhoef H, Haidar J, Hautvast J, 2003.Factors Associated with Stunting in Infants Aged 5-11 Months in the DodotaSire District, Rural Ethiopia. Journal Nutrition. 133: $1064-1069$.
Unicef, 1990. Strategy for improved nutrition of children and women in developing countries. New York.

Unicef, 2013. Improving Child Nutrition The achievable imperative for global progress. Diakses:www.unicef.org/media/files/nutrition report 2013.pdftanggal 24 Desember 2013

Unicef Indonesia, 2013. Ringkasan Kajian Gizi Ibu dan Anak, Oktober 2012. Akses www.unicef.org Tanggal 16 Desember 2013.

Walker SP, Chang SM, Powell CA, Simonoff E, McGregor SM, Early Childhood Stunting Is Associated with Poor Psychological Functioning in LateAdolescence and Effects Are Reduced by Psychosocial Stimulation, Journal Nutrition. 137: 2464-2469

World Health Organization, 2013.Nutrition Landcape Information System (NLIS) Country Profile Indicators : Interpretation quite (Serial Online) Akses : http://www.WHO.int//nutrition. Tanggal 17 Desember 2013 